\title{
IDEOLOGI MASYARAKAT BETAWI \\ DALAM NOVEL KRONIK BETAWI \\ KARYA RATIH KUMALA
}

\author{
Setia Naka Andrian ${ }^{1}$, Ahmad Rifai $^{2}$ \\ Prodi PBSI, FPBS, Universitas PGRI Semarang \\ setianakaandrian@gmail.com ${ }^{1}$,rifaiupgris@gmail.com²
}

\begin{abstract}
Abstrak
Pada penelitian ini dilakukan telaah dalam novel Kronik Betawi yang mengisahkan beragam cerita menarik yang merupakan potret kehidupan masyarakat Betawi. Dalam novel telah disebutkan bahwa ideologi hampir sama dengan keyakinan agama. Bedanya hanya pada kenyataan bahwa ideologi mampu dipindahkan, ditransmit melalui pendidikan, ajaran dan latihan tanpa melibatkan unsur rohani di dalamnya. Dalam hal ini kekuatan ideologi merupakan suatu sistem kepercayaan umum yang secara langsung memotivasi dan membenarkan segala hal yang diyakininya, karena ideologi sangat erat kaitannya dengan agama. Ideologi masyarakat Betawi yang mampu menunjukkan kekuatannya untuk menjadikan dirinya dan orang di sekitarnya untuk menemukan hidup kearah lebih baik. Masalah yang diteliti adalah bagaimana ideologi masyarakat Betawi dalam novel Kronik Betawi. Pendekatan yang digunakan dalam penelitian ini adalah pendekatan sosiologis dengan menggunakan kajian hermeneutika. Hasil penelitian yang dilakukan terhadap novel telah diuraikan mengenai ideologi masyarakat Betawi dalam hal mempertahankan kebudayaan. Hal tersebut ditunjukkan melalui keinginannya untuk selalu meyakini bahwa kebudayaan merupakan hal penting yang menjadi ciri khas dari sebuah dasar hidup keutuhan bermasyarakat, berbangsa dan bernegara. Selain itu, sesama masyarakat Betawi, mereka saling membela diri dan menyelematkan orang-orang yang membutuhkan pertolongan.
\end{abstract}

Kata Kunci: ideologi, masyarakat Betawi

\begin{abstract}
In this research has done the study of the novel Kronik Betawi that tells the variety of interesting stories which is a portrait of Betawi people's lives. In the novel has been mentioned that the ideology is similar to religious beliefs. The difference is only in the fact that ideology is able to be moved, transmitted through education, teaching and training without involving the spiritual element in it. In this case the power of ideology is a common belief system that directly motivates and justifies everything he believed, because ideology is closely associated with religion. Ideology Betawi people are able to demonstrate its strength to make himself and those around him to find the direction of a better life. Issues examined is how the ideology Betawi people on the novel Kronik Betawi. The approach used in this study was a sociological approach to the study of hermeneutics use. Results of a study of the novel has been described on the ideology of the community in terms of preserving Betawi
\end{abstract}


culture. This is shown through his desire to always believe that culture is an important thing that is being a characteristic of a basic integrity of the life of society, nation and state. Additionally, fellow Betawi people, they are defending themselves and rescuing people in need.

Keywords: ideology, Betawi society

\section{PENDAHULUAN}

Wellek dan Warren (1977:94) menyebutkan bahwa karya sastra merupakan sebuah lembaga masyarakat yang bermedium bahasa, sedang bahasa itu sendiri adalah ciptaan masyarakat. Oleh sebab itu, kebanyakan unsur-unsur dalam karya sastra bersifat sosial, yaitu norma-norma yang dapat tumbuh dalam masyarakat. Karya sastra juga mewakili kehidupan, sedang kehidupan adalah kenyataan sosial yang dalam diri sastrawan dapat menjadi objek penciptaan karya sastra.

Pengarang adalah anggota masyarakat, ia memiliki hak penuh untuk mengharapkan kebebasan dari masyarakatnya, yakni kebebasan berbicara, melontarkan gagasan, memandang setiap persoalan serta menentukan cara berkreasi sesuai dengan konsepnya. Sebalinya, masyarakat juga mempunyai alasan untuk mengharapkan tanggung jawab sosial pengarang. Mungkin berupa kritik atau proses terhadap situasi dan kondisi sosial tertentu yang tidak dikehendaki oleh masyarakat. Pengarang perlu merasa bertanggung jawab terhadap kehidupan masyarakatnya. Persoalan penderitaan dan dilema adalah masyarakat adalah miliknya. Oleh sebab itu, problem masyarakat sebenarnya juga problem karya sastra, karena karya sastra tidak hanya berfaedah bagi perseoragan, tetapi juga berfungsi sosial. Bahkan kalangan Marxisme berpendapat bahwa karya sastra harus berorientasi pada kepentingan masyarakat tanpa membedakan kelas berdasarkan norma politik dan etika.

Namun demikian, betapa pun besarnya kesadaran sosial yang dikandung karya sastra belum tentu menjamin nilai artistiknya. Ada karya sastra besar yang tidak mengungkapkan soalsoal masyarakat. Karya sastra yang berbicara tentang masyarakat bukan berarti pusat sari karya sastra, melainkan hanya cabang kecil dari karya sastra. Sebab, hakikatnya karya sastra bukan tiruan kehidupan, juga bukan pengganti sosiologi atau politik, tetapi karya sastra mempunyai nilai dan maksud sendiri (Sumardjo, 1982:15-16).

Karya sastra memiliki hubungan erat dengan sosial budaya. Sebagai bagian dari budaya, karya sastra mempunyai kaitan dengan segi-segi budaya lainnya, seperti bahasa, agama, bermacammacam kesenian, sistem sosial yang meliputi sistem nilai dalam masyarakat, tradisi, pola pikir dan sebagainya. Hal itu terlihat jelas jika memperhatikan fungsi sosial karya sastra dalam hubungan dengan fungsi sosial budaya. Sampai berapa jauh nilai karya sastra berkaitan dengan nilai sosial, bagaimana karya sastra berperan mengembangkan budaya, dan bagaimana pula karya sastra dapat dibentuk oleh nilai-nilai budaya, sehingga diadakan penelitian dengan judul Ideologi Masyarakat Betawi dalam Novel Kronik Betawi karya Ratih Kumala.

Dalam novel Kronik Betawi karya Ratih Kumala, masih terasa begitu besar penanaman ideologi bagi masyarakat Betawi dalam hal pertahanan budaya, pengembangan dan pencapaian citacita hidup. Konsep masyarakat Betawi yang dijadikan asas sebagai arah dan tujuan hidup yang baik dan benar. Kekuatan ideologi masyarakat Betawi dalam mempertahankan budayanya. Mengetahui tentang konsep masyarakat Betawi yang dijadikan asas sebagai arah dan tujuan hidup yang baik dan 
benar. Mengetahui tentang kekuatan ideologi masyarakat Betawi dalam mempertahankan budayanya.

\section{METODE PENELITIAN}

Pendekatan yang digunakan dalam penelitian ini adalah pendekatan sosiologis dengan menggunakan kajian hermeneutika. Masyarakat berada dalam pusat yang dipertimbangkan sepenuhnya dalam sebuah karya sastra. Manusia dalam masyarakat dianalisis melalui berbagai pemahaman, di antaranya terkait dengan proses pemahaman mulai dari masyarakat menuju individu-individu yang terus berkelanjutan dan berkesinambungan.

Hermeneutika menurut Ricoeur (2012:57) adalah teori tentang bekerjanya pemahaman dalam menafsirkan teks. Dalam hal ini hermeneutika dipakai untuk mengkaji refleksi budaya santri pada novel Kronik Betawi karya Ratih Kumala. Pendekatan sosiologis digunakan sebagai langkah awal untuk mengidentifikasi struktur pada novel Kronik Betawi karya Ratih Kumala. Selanjutnya, hermeneutika digunakan sebagai sarana menginterpretasi bagaimana tata nilai dan ideologi masyarakat Betawi novel Kronik Betawi karya Ratih Kumala.

\section{HASIL PENELITIAN DAN PEMBAHASAN}

\section{Konsep Masyarakat Betawi dalam Novel Kronik Betawi}

Wolff percaya bahwa segala aktivitas ideologis sebagai superstruktur ditentukan oleh aktivitas material sebagai infrastrukturnya. Ia pun percaya bahwa struktur kelas merupakan struktur yang terpenting yang menentukan struktur bentuk-bentuk ideologis itu. Akan tetapi, baginya hubungan antara kedua hal tersebut tidak lah langsung dan sederhana, melainkan melalui berbagai mediasi. Salah satunya adalah mediasi sosial dan historis (Faruk, 2005:58).

Masyarakat Betawi memiliki konsep tersendiri dalam hidupnya, yang dijadikan asas sebagai arah dan tujuan hidup yang baik dan benar. Mempertahankan dan mempertaruhkan segala untuk pencapaian hal yang dikehendaki. Misalnya dalam tokoh Salempang yang siap memamerkan kalau dirinya mampu menjadi imam untuk Enoh, anak Haji Jaelani. Maka Salempang pun suatu saat siap menjadi imam ketika shalat isya, di rumah Haji Jaelani ketika ngapel malam minggu. Seperti kutipan berikut;

Begitu jam sudah menunjukkan pukul sembilan malam, Haji Jaelani dengan suara sengaja dikeraskan berkata, "Noh... udah jam sembilan, lu udah sembayang Isya belom?” Ini semacam kode bahwa waktu pacaran usai. Salempang pun harus tahu diri, dan harus memiliki kemampuan membaca kode-kode semacam ini. Awalnya, ia segera meminta diri untuk beranjak pulang. Tetapi pada malam minggu keempat, Salempang malah memanfaatkan kode ini. Ujarnya, "Beh... maaf, apa saya bisa numpang salat Isya di sini? Saya juga belum salat, biar nanti di jalan pulang tenang Beh...," tentu saja Haji Jaelani tak bisa menolak ditumpangi salat, secara dia orang taat beragama. Dengan ragu ia memperbolehkan Salempang, bahkan dengan sengaja menyuruhnya mengimami ritual itu. Dalam hati, Haji Jaelani menantang Salempang, ingin menjajal kemampuan beragamanya. Dalam hati Salempang menerima tantangan Haji Jaelani, ia ingin unjuk gigi demi mengambil hati calon mertuanya. Ente jual, aye beli! (hlm 6). 
Salempang terlalu berani dengan orang tua Enoh, Haji Jaelani. Salempang benar-benar yakin bila dirinya akan mampu menunjukkan kefasihannya membaca surat-surat dalam shalat. Walaupun Haji Jaelani sangat memperhatikan Salempang ketika memimpin shalat jamaah. Karena bagaimanapun juga Haji Jaelani tak ingin salah memilih pasangan bagi anaknya, Enoh.

Ideologi yang sekarang ada, meskipun berbagai-bagai coraknya, memperlihatkan suatu persamaan: semuanya mencerminkan perubahan sosial yang cepat dan dasar di jaman kita ini. Perubahan inilah yang memaksa kita menimbang-nimbang kembali posisi dan tempat kita di dunia, dan tanggung jawab kita terhadap orang lain (Damono, 1979:51).

Setiap manusia memiliki tanggung jawab dalam hidupnya. Termasuk dalam hal tanggung jawab terhadap dirinya sendiri untuk orang lain akibat pencerminan sebuah perubahan sosial. Tanggung jawab terhadap diri sendiri, orang lain yang sedang didekati dan orang yang berada didekat orang yang didekati.

Hal tersebut terlihat pada Salempang yang memang benar-benar berani unjuk gigi di depan Haji Jaelani, calon mertuanya. Semua itu dilakukan Salempang karena rasa tanggung jawabnya terhadap dirinya sendiri ketika ingin diakui oleh orang tua Enoh. Ia sadar betul, orang tua Enoh tak akan pernah menerimanya apabila ia tak beragama baik. Hingga pada suatu malam ketika Salempang berkunjung ke rumah Enoh di malam hari, saat itu Salempang ingin unjuk gigi dihadapan orang tua Enoh. Memperlihatkan ketekunannya dalam beribadah dan menunjukkan seberapa fasih ketika ia membacakan surat-surat Alquran dalam shalat. Saat itu pula ketika shalat berjamaah, Enoh merasa takut kalau sampai Salempang tak fasih membaca Al-Fatihah dan tidak terpeleset lidahnya di tengah shalat, agar orang tuanya merasa mantap dengan lelaki pilihannya, dalam kutipan berikut;

Ia sadar betul Haji Jaelani tak mungkin mau menerimanya apabila ia tak beragama baik. Dalam hati, Enoh deg-degan, berdoa berulang-ulang semoga Salempang fasih baca Al-Fatihah dan tidak terpeleset lidahnya di tengah salat, agar babehnya merasa mantap dengan lelaki pilihannya (hlm $6)$.

Selain sebagai tanggung jawab terhadap diri sendiri untuk orang lain yang didekati dan untuk orang lain yang ada didekat orang yang didekati, hal tersebut juga merupakan perwujudan pemertahanan ideologi dalam sebuah keluarga. Merupakan sebuah konsep yang dijadikan asas sebagai arah dan tujuan hidup yang baik dan benar. Ketika Haji Jaelani tak ingin anaknya dikawini oleh lelaki sembarangan. Haji Jaelani ingin anaknya memiliki suami yang benar-benar beragama baik. Maka tidak salah jika Haji Jaelani benar-benar ingin menguji siapa pun yang mendekati atau pun yang ada di dekat Enoh dalam hubungan spesial/ pacar.

Individu adalah seorang manusia yang tidak hanya memiliki peranan khas di dalam lingkungan sosial-nya, melainkan juga mempunyai kepribadian serta pola tingkah laku spesifik dirinya. Persepsi terhadap individu atau hasil pengamatan manusia dengan segala maknanya merupakan suatu keutuhan ciptaan Tuhan yang mempunyai tiga aspek melekat pada dirinya, yaitu aspek organik jasmaniah, aspek psikis rohaniah, dan aspek sosial kebersamaan. Ketiga aspek tersebut saling mempengaruhi, keguncangan pada satu aspek akan membawa akibat pada aspek yang lainnya. Makna manusia menjadi individu apabila pola tingkah lakunya hampir identik dengan tingkah laku massa yang 
bersangkutan. Proses yang meningkatkan ciri-ciri individualitas pada seseorang sampai ia adalah dirinya sendiri, disebut proses individualisasi atau aktualisasi diri. Inividu dibebani peranan yang berasal dari kondisi kebersamaan hidup, maka muncul struktur masyarakat yang akan menentukan kemantapan masyarakat. Konflik mungkin terjadi karena pola tingkah laku spesifik dirinya bercorak bertentangan dengan peranan yang dituntut oleh masyarakat dari dirinya. (Soelaeman, 1987:114).

Hal tersebut terlihat pada tokoh Juned, yang merupakan orang tua Jaelani, Jarkasi dan Juleha. Juned merupakan anak yatim piatu yang hidup seorang diri. Benar-benar hidup sendiri tanpa sanak saudara. Mempertahankan ke-individuannya dalam hidup bermasyarakat. Menunjukkan kepada orangorang disekitarnya bila ia mampu menjalani hidup walau seorang diri. Dengan penuh semangat dan tentunya dengan diimbangi kerja keras demi kelangsungan hidupnya serta pemertahanan individunya oleh ciri khas tingkah laku yang benar-benar identik dengan dirinya sendiri. Juned bekerja pada Tuan Henk. bekerja keras dengan penuh ketekunan kepada seorang Belanda yang memiliki peternakan sapi perah di Kebayoran yang tak jauh dari tempat tinggalnya. Tuan Henk bagi Juned adalah orang baik. Tuan berambut jagung itu memberi upah yang layak untuk Juned, karena Juned pun adalah seorang pekerja yang tekun dan bertanggung jawab. Bekerja dengan mengantarkan susu kepada pelanggannya, dalam kutipan berikut;

Jaman Belanda dulu, Junaedi, atau yang kerap dipanggil Juned (nama ini kemudian diambil sebagai nama anak kedua Jaelani, kakak kandung Jarkasi), ikut orang Belanda yang punya peternakan sapi perah di Kebayoran. Bung Juned, demikian orang-orang dulu memanggilnya. Panggilan 'bung' tidak tiba-tiba muncul. Awalnya dia dipanggil 'bang' seperti umumnya masyarakat betawi memanggil untuk tiap laki-laki dewasa. Bagaimana sebutan 'bung' kemudian bisa menempel pada Juned? (hlm 8).

Ceritanya dimulai sebelum jaman kemerdekaan. Kejadiannya setelah Sumpah Pemuda dan sebelum Jepang datang. Juned, anak yatim piatu, bekerja untuk seorang Belanda yang memiliki peternakan sapi perah di Kebayoran, tak jauh dari tempat tinggalnya. Tuan Henk bagi Juned adalah orang baik. Tuan berambut jagung itu memberinya upah yang layak untuk mengantar susu kepada pelanggannya. Hal yang paling disukai Juned dari pekerjaannya adalah, ia boleh membawa pulang sepeda kumbang yang kerap digunakannya untuk mengantar susu tiap pagi dan sore (Kumala, 2006:27-28).

Juned mempertahankan hidupnya walau hidup dengan seorang diri. Dia merupakan seorang manusia yang tidak hanya memiliki peranan khas di dalam lingkungan sosial-nya, melainkan juga mempunyai kepribadian serta pola tingkah laku spesifik dirinya. Karena hidup seorang diri, maka Juned pun benar-benar menjadikan dirinya sebagai seorang pekerja yang baik dan jujur. Dia selalu mematuhi majikannya, dengan selalu mengantarkan kepada tiap-tiap pelanggannya walaupun majikannya itu adalah orang Belanda. Namun, bagi Juned, dia bekerja kepada orang Belanda dengan cara halal. Bukan menjadi tentara mereka yang sewenang-wenang menindas masyarakat, kutipannya sebagai berikut; 
Juned memulai hari-harinya dengan datang ke peternakan tempat ia mengambil susu. Lalu ia mengantarkan botol-botol susu itu kepada para pelanggannya yang kebanyakan adalah orang Belanda, sekaligus mengambil botol kosong. Para pelanggan tersebut juga membayar uang susu kepada Juned. Untuk yang satu ini, Juned memiliki sebuah buku catatan yang ia selipkan di sepedanya. Tuan Henk menerimanya bekerja karena ia segelintir dari sedikit orang yang waktu itu bisa baca-tulis. Setelah ia kembali ke peternakan dan mengembalikan botol-botol kosong sekaligus setor uang bayaran pelanggan pada bagian keuangan, ia bisa pulang. Dengan sepeda kumbang itu, tentu saja. juned biasa keliling-keliling kota. Sekitar jam tiga sore, ia mengayuh kembali sepedanya ke peternakan, mengambil botol-botol susu yang baru dan mengantarnya kepada pelanggan sore hari (hlm 28).

Norma adalah aturan, implisit, maupun eksplisit mengenai perilaku. Dari aturan-aturan ini kita mengembangkan harapan tertentu tentang bagaimana orang akan bersikap. Kita memiliki normanorma mengenai seks, makan, bertemu, menasihati, membesarkan anak, sebenarnya, mengenai setiap aspek dalam kehidupan manusia. Bahkan dua orang yang bertemu untuk yang pertama kalinya mengikuti norma-norma seperti cara berkomunikasi yang sesuai: “Ada aturan-aturan untuk memulai dan mengakhiri pembicaraan; ada norma-norma untuk menyelaraskan proses memandang pembicara dan dipandang oleh pembicara; ada etika untuk mengawali dan mengakhiri suatu pertemuan" (Goffman, 1972). Norma-norma muncul dalam sejumlah tingkat sosial dan seringkali dialihkan dari suatu hubungan ke hubungan lainnya, dengan ukuran keberhasilan yang tidak selalu sama. Beberapa norma dipakai bersama oleh hampir semua anggota budaya tertentu, norma-norma lainnya khusus berlaku dalam keluarga, kelompok etnik, masyarakat atau suatu daerah dalam sebuah negara. Misalnya di beberapa daerah di California, berendam tanpa busana sehabis makan malam di dalam sebuah Jacuzzi merupakan kelaziman, tetapi mungkin tidak demikian halnya pada acara makan malam yang melibatkan tetamu yang berasal dari Amerika Bagian Barat-Tengah dan Timur Laut. (Tubbs, Moss; 2005:3-4).

Dalam hal ini, terdapat aturan tersendiri mengenai perilaku yang ada pada diri sendiri. Perilaku Juned yang tetap teguh pada aturan-aturan yang seakan mengikat dirinya sendiri walaupun tidak ada aturan yang mengikatnya secara langsung, misalnya aturan tentang keharusan untuk bekerja menghidupi dirinya walaupun hidup seorang diri. Juned tetap setia untuk bekerja kepada majikannya, Tuan Henk, untuk mengantarkan susu kepada pelanggan-pelanggannya.

Hingga tiba pada suatu hari, terdapat aturan-aturan tersendiri yang memperkuat dirinya sendiri atau kelompok yang terdapat aturan tertentu dalam sebuah masyarakat. Aturan yang ada pada beberapa perampok yang menghadang Juned di tengah jalan. Untuk melakukan sesuatu yang tidak diinginkan orang lain tapi tetap saja dilakukan oleh beberapa perampok tersebut, karena aturan-aturan tadi ketika barang siapa yang lewat harus memberikan jatah uang kepada mereka. Juned dihadang oleh beberapa perampok. Juned dimintai uang, tapi Juned tidak punya uang. Perampok-perampok tak percaya akan hal itu, lalu Juned memperlihatkan semua saku yang ada di baju dan celananya. Karena memang Juned benar-benar tidak punya uang. Lalu pada akhirnya perampok-perampok itu meminta susu yang di bawanya. 
Peraturan-peraturan tertentu atau norma-norma yang berkembang dalam budaya masyarakat tertentu pula juga terdapat pada diri Jiung. Seorang kakek-kakek yang memiliki aturan tersendiri yang sangat mengerat kuat dalam dirinya. Ketika dia tidak berkenan bila ada orang yang mengganggu dan berlaku sesuatu yang tidak dikehendakinya di jembatan yang merupakan daerah kekuasaannya. Maka ketika ada sebuah keributandi jembatan yang dilewati Juned, Jiung merasa sangat terganggu dan sangat tidak menghendaki hal itu terjadi seenak-enaknya di daerah kekuasaannya. Apa lagi sebuah perampokan, sungguh itu merupakan hal yang sangat tidak diinginkan Jiung bila terjadi di daerah kekuasaannya. Maka tak lama kemudian setelah beberapa susu diminum oleh kawanan perampok tersebut, datanglah Jiung menyelamatkan Juned. Karena Jiung adalah penguasa jalan itu merasa terganggu atas tindakan biadab dari perampok-perampok tersebut kepada Juned, berikut kutipannya;

Ketika ia hampir melewati jembatan Jiung, dua orang berpakaian hitam-hitam dengan tampang dekil menyetopnya. Mereka tiba-tiba saja melompat dari balik pepohonan di sekitar jalan tanah. Juned hampir tak bisa mengendalikan sepedanya, untung ia cekatan. Sebelah kakinya langsung turun ke tanah, menahan sepeda yang penuh berisi botolan susu agar tak jatuh.

Tiba-tiba seorang lelaki tua bercelana pangsi hitam dengan peci dan sarung dibebat di pinggang melompat ke arah mereka.

“Ciaaaaat...! teriaknya. Juned memejamkan mata. Sekejap kemudian dia mendengar dua suara menjerit mengaduh-aduh (hlm 28-30).

Dalam hal tersebut Juned adalah penggambaran masyarakat Betawi yang benar-benar memiliki dasar hidup, memiliki aturan-turan atau norma-norma tersendiri dan tetap teguh pada dirinya. Dia akan tetap mempertahankan dasar hidupnya hingga mencapai tujuan hidup ke arah yang baik dan benar. Dengan teguh terhadap norma-norma muncul dalam sejumlah tingkat sosial dan seringkali dialihkan dari suatu hubungan ke hubungan lainnya, dengan ukuran keberhasilan yang tidak selalu sama. Sehingga ada kalanya beberapa norma dipakai bersama oleh hampir semua anggota budaya tertentu, norma-norma lainnya khusus berlaku dalam keluarga, kelompok etnik, masyarakat atau suatu daerah dalam sebuah negara. Dalam hal ini Juned membentuk hidupnya sehingga dia mampu mempertahankan keberadaannya dalam masyarakat. Seseorang yang mengawali hidupnya yang benar-benar dari nol dan akhirnya dapat menemukan jalan untuk mempertahankan kehidupannya, hingga akhirnya dapat berkeluarga, beristri dan memiliki keturunan, dalam kutipan berikut;

Siang itu juga, Juned menggenjot sepedanya ke daerah Kemayoran. Dia menuju rumah Haji Ung. Meminta nasihat darinya, perihal perkawinan. Jawabannya sungguh mengejutkan; Haji Ung bersedia menikahkan Juned dan Ipah.

Begitulah, alkisah Juned yang tak dimulai dengan cinta secuil pun. Hanya rasa kasihan dan tanggungjawab yag mewakili kebersediaan Juned menikahi Ipah. Kelak, dari Juned Ipah melahirkan tiga anak' Jaelani, Jarkasi dan Juleha. Dua laki-laki, satu bontot perempuan (hlm 36$37)$.

Akhirnya pun Juned mampu mempertahankan hidupnya yang tadinya benar-benar berawal dari nol, kini telah mampu membentuk sebuah keluarga dan memiliki keturunan yang kelak akan melanjutkan segala hal yang belum sempat dia lakukan atau mungkin yang belum dapat dilakukan 
dalam hidupnya. Semua dilakukan karena pada waktu dulu, Juned telah berjuang mempertahankan hidupnya. Dengan kejujurannya maka Juned telah mendapatkan warisan dari Tuan Henk majikannya, ketika Juned telah menyelamatkan nyawa Tuan Henk dan segenap keluarganya. Karena pada waktu itu, Tuan Henk dirampok besar-besaran oleh orang-orang Jepang. Memporak-porandakan seisi rumah dan membawa lali semua barang-barang berharga yang ada di rumahnya. Tapi untungnya Tuan Henk bisa kabur, dan pergi ke sebuah rumah di kebun karet. Hanya Ipah, seorang pembantu yang tertinggal di rumahnya dalam keadaan menangis dilihat Juned, dalam kutipan berikut;

"Masyaallah... kirain kuntilanak nangis," ujarnya kaget. Anak perempuan itu diam saja. "Tuan Henk ke mana?" dia masih diam, gemetar. Maka dengan lembut Juned membantunya berdiri dan menyeka air matanya dengan kemejanya. Perempuan itu bercerita tersendat-sendat, bahwa Jepang datang mengambil perhiasan milik Nyonya Henk dan mengacak-acak rumah mengambil barangbarang dari perak. Seorang pembantu perempuan yang juga bekerja di situ dibawa pergi, Ipah, nama pembantu kecil itu beruntung bisa sembunyi dan tak ketahuan Jepang. Sekarang keluarga Henk pergi ke Karet, mereka bersembunyi di sana (hlm 33-34).

Juned sangat berhati mulia, dia benar-benar ingin mencari keberadaan Tuan Henk dan keluarganya. Rasa hormat Juned terhadap Tuan Henk sangat besar, karena Tuan Henk bagi Juned telah mau memberikan pekerjaan terhadapnya dan mempercayainya sebagai seseorang yang hidup seorang diri tanpa sanak saudara.

Konsep kepribadian dasar atau basic personality structure, yaitu "semua unsur kepribadian yang dimiliki bersama oleh sebagian besar dari warga masyarakat tersebut". Kepribadian dasar itu ada karena semua individu warga masyarakat itu mengalami pengaruh lingkungan kebudayaan yang sama selama masa pertumbuhannya. Metodologi untuk mengumpulkan data kepribadian bangsa itu bangsa itu adalah dengan cara mengumpulkan sampel dari individu-individu warga masyarakat yang menjadi objek penelitian, kemudian tiap individu dalam sampel itu diteliti kepribadiannya dengan testes psikologi. Hasilnya tentu berupa suatu daftar ciri-ciri watak yang merupakan bagian terbesar dari individu-individu dalam sampel tadi (Fathoni, 2006:41-42).

Hal tersebut tercermin pada diri Juned yang memiliki watak pengabdian yang begitu kuat terhadap majikannya, Tuan Henk. Kepribadian baik yang dimilikinya membuatnya kuat menakhlukkan dirinya sendiri yang lebih mementingkan orang lain (Tuan Henk dan keluarganya). Terlihat jelas ketika suatu saat Juned pergi mencari keberadaan Tuan Henk. Dia bertanya-tanya kepada semua orang, hingga suatu saat langkah Juned terbawa hingga ke rumah yang dihuni oleh Tuan Henk dan keluarganya. Akhirnya Juned bertemu dengan Tuan Henk dan keluarganya, dalam kutipan berikut;

Memang dasar, orang niat baik selalu ditolong Yang Kuasa. Ini betul-betul dipercaya Juned. Entah bagaimana, ia akhirnya bisa menemukan tempat tinggal Tuan Henk. lelaki berambut jagung itu menyambutnya dengan gembira, apalagi Juned membawa berbotol-botol susu perah. Ada sekitar tujuh orang aseli Indonesia ikut bersembunyi di situ, mereka adalah para pembantu yang bekerja di rumah Tuan Henk yang lama. Semua ikut sembunyi di situ, mengungsi demi keamanan. Tidak seperti tempo dulu, orang Belanda bisa berjemur sore-sore sambil ngeteh di beranda depan. Sekarang lain keadaannya. Semua lebih suka berada di dalam rumah (hlm 40). 
Akhirnya Juned dapat menemukan keberadaan Tuan Henk dan keluarganya. Juned melihat keresahan mereka. Hingga Juded benar-benar terpanggil ketika yakin untuk menolong mereka yang sedang bersembunyi dari kejaran tentara-tentara Jepang. Maka kedatangan Juned pun sangat disambut baik oleh Tuan Henk sekeluarga.

Tiap kebudayaan yang hidup dalam suatu masyarakat yang berwujud sebagai komunitas desa, atau kota, atau sebagai kelompok adat yang lain, bisa menampilkan suatu corak yang khas. Hal itu terlihat oleh orang luar yang bukan warga masyarakat bersangkutan. Seorang warga dari suatu kebudayaan yang telah hidup dari hari ke hari di dalam lingkungan kebudayaannya biasanya tidak melihat corak khas itu. Sebaliknya, terhadap kebudayaan tetangganya, ia dapat melihat corak khasnya, terutama mengenai unsur-unsur yang berbeda menyolok dengan kebudayaan sendiri. (Fathoni, 2006:46).

Hal tersebut terlihat pada diri Juned yang berada dalam lingkaran kebudayaan yang hidup dalam suatu masyarakat yang berwujud sebagai komunitas desa. Karena dalam sebuah kehidupan masyarakat desa tiap-tiap warganya memiliki rasa solidaritas yang sangat kuat. Saling tolongmenolong, gotong-royong, saling membantu apa bila ada yang membutuhkan, merupakan sebuah kebudayaan yang benar-benar tertanam erat pada tiap-tiap individunya. Walaupun membantu atau menolong warga yang bukan berasal dari bangsanya. Maka tak heran jika Juned memiliki kerelaan yang besar untuk membantu Tuan Henk dan keluarganya ketika membutuhkan pertolongan saat tercekam dalam kejaran tentara-tentara Jepang.

Terlihat ketika tentara Jepang mendekat ke arah rumah Tuan Henk. semua merasa ketakutan, termasuk Tuan Henk dan keluarganya. Tapi tidak untuk Juned. Karena tentara Jepang semakin mengepung mendekati rumah, maka Juned pun keluar dari rumah, dengan membaca mantra dan nyanyian dari gurunya jiung, maka orang-orang Jepang tak mampu melihatnya. Juned membantengi rumah yang di huni Tuan Henk dan keluarganya tersebut. Lalu pada akhirnya tentara-tentara Jepang itu pun pergi, dalam kutipan berikut;

Juned langsung ngeloyor ke luar rumah. Dia ntara derap suara sepatu-sepatu tentara Jepang dan bahasa Jepang yang yang tegas dan kasar, suara tembakan-tembakan yang muncul sekali-sekali, juga suara teriakan para perempuan, tiba-tiba terdengar suara Juned menembang. Bernyanyi berulang-ulang di depan rumah sambil keliling. Seorang jongos mengintip dari balik Jendela. Ia melihat Juned sedang keliling sambil nembang bahasa Sunda bercampur Arab dari sebuah surat di Quran. Di depan Juned, tentara-tentara Jepang bersliweran. Jongos itu cepat-cepat menunduk lagi, ketakutan demi melihat tentara Jepang. Sekaligus ia heran, kenapa tentara-tentara itu tak melihat Juned yang seliweran dengan tenang di depan rumah. Keadaan itu berlanjut selama tiga jam ke depan, hingga hari menjelang maghrib dan tentara-tentara Jepang itu pergi menyisakan sesak dan ketakutan. Juned masuk ke rumah lagi begitu yakin tak ada seorang tentara Jepang pun di sekitar situ (hlm 41-42).

Tuan Henk dan keluarganya sangat berterimakasih kepada Juned. Hingga karena terlalu berterimakasihnya Tuan Henk terhadap Juned yang telah menyelamatkan Tuan Henk dari ancaman tentara Jepang, maka Tuan Henk memberikan rumahnya dan semua kebun karet yang dimilikinya. 
Tuan Henk dan keluarganya pun memutuskan untuk pulang ke tanah airya, Belanda. Dan tak akan kembali lagi ke Indonesia, dalam kutipan berikut;

Ketika Tuan Henk balik ke Belanda, semua rumah dan tanahnya di Karet dan benda-benda milik keluarga Tuan Henk, termasuk sapi-sapinya yang tinggal enam ekor diberikan pada Juned. Sementara rumah dan peternakanmilik Tuan Henk di Kebayoran dijual murah kepada seorang Belanda yang masih bertahan di Indonesia. Uang hasil jualannya akan ia gunakan sebagai modal usaha di Belanda (hlm 42-43).

Keberadaan Juned atas perjuangannya telah menemukan titik terang. Atas segenap kesabaran dan kejujurannya mengabdi kepada majikannya, Tuan Henk. Juned dapat menjalani hidupnya kembali walaupun dia tak lagi bekerja kepada Tuan Henk. Juned telah mendapatkan harta benda dari Tuan Henk atas jasa yang tulus darinya untuk majikannya tersebut. Semua itu atas modal kejujuran dan kesabaran hingga kepercayaan pun tertanamkan setiap saat kepada Juned.

\section{Ideologi Masyarakat Betawi dalam Novel Kronik Betawi}

Ideologi hampir sama dengan keyakinan agama. Bedanya hanya pada kenyataan bahwa ideologi mampu dipindahkan, ditransmit melalui pendidikan, ajaran dan latihan tanpa melibatkan unsur rohani didalamnya. Ideologi adalah suatu sistem kepercayaan umum yang secara langsung memotivasi dan membenarkan. Ideologi bersifat formal, terstruktur, dan melibatkan logika tertentu, sering nampak dalam bentuk ilmu pengetahuan atau pengetahuan obyektif. Ideologi adalah filsafat, sekaligus, ilmu pengetahuan, agama, dan imaginasi (Setiawan, 2009:1).

Telah disebutkan sebelumnya bahwa ideologi hampir sama dengan keyakinan agama. Bedanya hanya pada kenyataan bahwa ideologi mampu dipindahkan, ditransmit melalui pendidikan, ajaran dan latihan tanpa melibatkan unsur rohani didalamnya. Dalam lingkungan masyarakat Betawi berkembang bela diri Pencak Silat yang di dalamnya terdapat ajaran-ajaran yag bersinggungan dengan agama Islam. Pencak berarti jurus, sedang silat berarti salat atau sembahyang. Jadi pencak silat bukan untuk mencari musuh atau berkelahi. Selain itu, silat juga kependekan dari silaturahmi, dalam kutipan berikut;

Maka sejak hari itu, Juned berlatih pencak silat. Jiung menjelaskan panjang lebar tentang pencak silat. 'Pencak' berarti jurus sedang 'silat' berarti salat atau sembahyang. Jadi pencak silat bukan untuk mencari musuh atau berkelahi. Selain itu, 'silat' juga kependekan dari 'silaturahmi' (hlm $33)$.

Maka sangatlah jelas bila ideologi merupakan suatu sistem kepercayaan umum yang secara langsung memotivasi dan membenarkan. Ideologi bersifat formal, terstruktur, dan melibatkan logika tertentu, sering nampak dalam bentuk ilmu pengetahuan atau pengetahuan obyektif. Ideologi adalah filsafat, sekaligus, ilmu pengetahuan, agama, dan imaginasi. Dalam hal ini terdapat keterkaitan yang erat antara ideologi dan agama, tentang ajaran-ajaran baik yang mendasari sebuah kebudayaan yang berkembang dalam masyarakat Betawi.

Orang Betawi sebagian besar menganut agama Islam, tetapi yang menganut agama Kristen; 
Protestan dan Katholik juga ada walau hanya sedikit sekali. Di antara suku Betawi yang beragama Kristen, ada yang menyatakan bahwa mereka adalah keturunan campuran antara penduduk lokal dengan bangsa Portugis. Hal ini wajar karena pada awal abad ke-16, Surawisesa, Raja Sunda mengadakan perjanjian dengan Portugis yang membolehkan Portugis membangun benteng dan gudang di Pelabuhan Sunda Kalapa sehingga terbentuk komunitas Portugis di Sunda Kalapa (Alfia, 2008:1).

Hal tersebut terlihat jelas dalam tokoh Jiung, merupakan orang betawi yang sudah tua. Namun, Jiung merupakan sosok orang yang kuat dan ditakuti dengan kehebatan pencak silatnya dan ilmunya yang hebat dengan nyanyiannya. Tembang yang berbahasa sunda dan terdapat bacaan-bacaan Alquran yang ketika dinyanyikan akan mampu membantengi dirinya sendiri juga dapat membantengi sebuah rumah atau tempat yang dikelilinginya. Hingga orang Jepang pun dapat ketakutan dan lari, dalam kutipan berikut;

Semua tahu, yang dimaksud Jiung keliling rumah adalah berjaga-jaga dengan cara membuat pagar gaib yang tak bisa tembus bom apalagi peluru. Jaman itu, mencari ilmu bukan berarti bacatulis, melainkan mencari ilmu agar tak kalah dari musuh. Penghuni bentengan desak-desakan. Ibu memeluk anak, anak tak mau lepas dari pelukan ibunya. Kebanyakan komat-kamit berdoa sebisanya, seingat mereka bisa diucapkan surat-surat dalam Quran. Tak sedikit yang bengong, takut kedapatan bom nyasar. Ada juga anak yang menangis tertahan-tahan, sementara ibunya membujuk agar tak ribut. Dari dalam bentengan, suara berdebum terdengar jelas, bangunanbangunan yang hancur kena hantam bom terdengar seperti berton-ton pasir jatuh dari awan. Pesawat-pesawat Jepang seliweran di udara bunyinya seperti lebah lewat. Lamat-lamat diantara itu semua, terdengar suara seorang laki-laki nembang. Tak jelas apa yang diucapkan, yang pasti bernada berulang-ulang. Tiba-tiba..., bruuuut...! Suara nyaring angin kejepit terdengar, disusul bau tajam campuran antara jengkol dan duren busuk. Kontan orang-orang yang ada di dalam bentengan marah-marah dan menyumpah-nyumpah (hlm 38).

Maka tak salah lagi jika ideologi dalam diri pribadi masyarakat sangat berpengaruh dan saling berkait dengan agama tentang berbagai ajaran-ajarannya. Tentang tembang doa ayat-ayat dari Alquran yang dilakukan oleh Jiung. Karena hal tersebut merupakan suatu ibadah yang selalu setiap saat harus dilakukan ketika waktunya, ketika ada yang membutuhkan dan ketika ada yang memerlukan.

Berbagai unsur kebudayaan yang ada dalam masyarakat manusia berfungsi untuk memuaskan hasrat naluri kebutuhan hidup makhluk manusia (Basic Human Needs). Dengan demikian, unsur "Kesenian", misalnya berfungsi memuaskan hasrat naluri manusia akan keindahan; unsur sistem pengetahuan berfungsi memuaskan hasrat naluri untuk tahu. Karena itu, apabila seorang ahli dapat membuat suatu daftar yang lengkap dari semua hasrat naluri manusia di sebelah kiri, maka disebelah kanan ia dapat membuat daftar dari unsur-unsur kebudayaan manusia yang sejajar dengan tiap hasrat tadi. Tetapi harus diingat bahwa tentu ada unsur-unsur kebudayaan yang tidak hanya berfungsi memuaskan satu hasrat naluri saja, tetapi lebih dari satu. "Keluarga" misalnya dapat dianggap berfungsi memenuhi hasrat manusia akan prokreasi, yaitu melanjutkan jenisnya, serta mengamankan keturunannya. "Rumah" dapat dianggap berfungsi untuk memenuhi hasrat manusia akan perlindungan 
fisik, tetapi juga untuk keindahan atau untuk menaikkan gengsi. (Fathoni, 2006:37-38).

Hal tersebut terlihat pada Jiung yang tidak berhenti begitu saja dalam hal sembahyangnya dalam pencak silat. Ilmu yang dimilikinya diturunkan kepada Juned dan orang-orang yang pernah merampok Juned. Orang-orang yang dipercaya oleh Juned dan telah dianggap sebagai keluarga, yang berfungsi memenuhi hasrat manusia akan prokreasi. Agar kelak ada yang menuruni segala sesuatu yang mungkin kelak dapat diperlukan oleh masyarakat yang membutuhkan bantuan. Jiung hanya berharap agar pencak silat yang diturunkannya bukan untuk berkelai atau mencari musuh. Tapi untuk membela diri dan menyelematkan orang-orang yang membutuhkan pertolongan, tidak untuk semacam perlindungan fisik, tetapi juga tidak untuk keindahan atau untuk menaikkan gengsi semata, berikut kutipannya;

Maka sejak hari itu, Juned berlatih pencak silat. Jiung menjelaskan panjang lebar tentang pencak silat. 'Pencak' berarti jurus sedang 'silat' berarti salah satu sembahyang. Jadi pencak silat bukan untuk mencari musuh atau berkelahi. Selain itu, 'silat' juga kependekan dari 'silaturahmi'. Juned ternyata tidak sendiri, Haji Ung juga mengangkat dua gerilyawan yang sempat merampok Juned tempo hari. Keduanya kelihatan beda setelah bebersih. Juned sempat tak mengenali, kalau mereka tidak langsung menyalami tangan Juned saat bertemu kembali (hlm 33).

Haji Ung menurunkan ilmu pencak silatnya tidak memandang dengan siapa akan diturunkan, tetapi terhadap siapa saja yang mau dan berminat untuk mendapatkan ilmu pencak silat darinya. Itu semua merupakan sebuah bukti nyata ketika Haji Ung benar-benar ingin menurunkan ilmu yang dimilikinya demi terwujudnya maksud dari pencak silat tersebut, yang berarti sembahyang dan silaturahmi, bukan untuk mencari musuh ataupun berkelahi.

Sifat campur-aduk dalam dialek Betawi adalah cerminan dari kebudayaan Betawi secara umum, yang merupakan hasil perkawinan berbagai macam kebudayaan, baik yang berasal dari daerah-daerah lain di Nusantara maupun kebudayaan asing. Dalam bidang kesenian, misalnya, orang Betawi memiliki seni Gambang Kromong yang berasal dari seni musik Tiongkok, tetapi juga ada Rebana yang berakar pada tradisi musik Arab, Keroncong Tugu dengan latar belakang PortugisArab,dan Tanjidor yang berlatarbelakang ke-Belanda-an. Secara biologis, mereka yang mengaku sebagai orang Betawi adalah keturunan kaum berdarah campuran aneka suku dan bangsa. Mereka adalah hasil kawin-mawin antaretnis dan bangsa di masa lalu. Berbagai kesenian tradisional Betawi dapat berkembang dan digemari oleh masyarakat luas, bukan hanya masyarakat Betawi. Kesenian Betawi tersebut antara lain: lenong, topeng blantik, tari topeng, ondel-ondel, tari ronggeng topeng dan lain-lain. Seni suara dan seni musiknya adalah: sambrah, rebana, gambang kromong, tanjidor dan sejenisnya. Bahkan wayangpun ada, wayang kulit Betawi mengunakan bahasa dialek Melayu Betawi. (Alfia, 2008:1).

Cerminan masyarakat Betawi secara umum terlihat pada tokoh Jarkasi, seorang seniman gambang kromong yang merupakan senuah kelompo musik yang berkembang di daerah Betawi. Jarkasi adalah anak kedua dari Juned. Dia adalah seorang seniman yang juga menuruni jiwa seninya kepada anaknya, Edah. Edah menyukai menari, hingga Jarkasi dan anaknya sering dalam satu panggung pementasan. Jarkasi sebagai salah satu pengiring dalam kelompok musik gambang 
kromong dan Edah merupakan salah seorang pemain lenong, Jarkasi sangat mendukung dengan bakal menari yang dimiliki anaknya.

Lenong sebagai tontonan, sudah dikenal sejak 1920-an. Almarhum Firman Muntaco, seniman Betawi terkenal, menyebutnya kelanjutan dari proses teaterisasi dan perkembangan musik Gambang Kromong. Jadi, Lenong adalah alunan Gambang Kromong yang ditambah unsur bodoran alias lawakan tanpa plot cerita. Kemudian berkembang menjadi lakon-lakon berisi banyolan pendek, yang dirangkai dalam cerita tak berhubungan. Lantas menjadi pertunjukan semalam suntuk, dengan lakon panjang utuh, yang dipertunjukkan lewat ngamen keliling kampung. Selepas zaman penjajahan Belanda, lenong naik pangkat, karena mulai dipertunjukkan di panggung hajatan. Baru di awal kemerdekaan, teater rakyat ini murni menjadi tontonan panggung. Saat itu, dekornya masih sangat sederhana, berupa layar sekitar $3 \times 5$ meter bergambar gunung, sawah, hutan belantara dengan pepohonan besar, rumahrumah kampung, laut dan perahu nelayan serta balairung istana dengan tiang-tiangnya yang besar. Alat penerangannya pun tradisional, berupa colen, obor tiga sumbu yang keluar dari ceret kaleng berisi minyak tanah. Sebelum meningkat jadi petromaks. Walaupun terus menyesuaikan diri dengan maunya zaman, untuk terus survive, lenong harus berjuang keras. Dan ini tak mudah. Tahun 60'an, masih dengan mengandalkan durasi pertunjukan semalam suntuk dan konsep dramaturgi sangat sederhana, lenong mulai kedodoran. "Rasanya, kami seperti berada di pinggir jurang," cetus S.M Ardan, sastrawan dan sineas Betawi yang kini aktif di Pusat Perfilman Usmar Ismail, Kuningan, Jakarta. (Alfia, 2008:1).

Hal tersebut merupakan sebuah penguatan yang dilakukan oleh Jarkasi dalam hal pelestarian kebudayaan. Mempertahankan kebudayaan yang ada, yang merupakan kebudayaan khas masyarakat Betawi. Maka tak heran jika Jarkasi sangat antusias dan berjuang keras dalam hal menurunkan bakat yang dimilikinya kepada anaknya, Edah. Hanya saja istri Jarkasi, Eden tak begitu suka dengan hal tersebut.berikut kutipannya;

Edah mau saja disuruh jadi pemain lenong. Ia menikmati perannya sebagai anak bawang. Ketika pulang, Jarkasi bercerita pada istrinya sambil tertawa-tawa, bahwa Edah tadi ikut latihan lenong sementara ia dan kelompoknya mengiringi dengan gambang kromong. Respon Eden sangat bertolak belakang dengan yang awalnya diduga Jarkasi. Eden langsung marah, dan memaksa Jarkasi bersumpah untuk tidak membiarkan Edah jadi pemain lenong. Maka peran Edah pun akhirnya dicoret (hlm 46-47).

Termasuk juga gambang kromong yang merupakan salah satu alat musik yang berkembang pada masyarakat Betawi, maka tak menutup kemungkinan Jarkasi untuk menurunkan semua itu untuk anaknya. Walaupun ada anggapan kalau seorang penari/ biduan panggung banyak membuat kekacauan pada kalangan penonton laki-laki. Tapi Jarkasi berniat bahwa semua itu bukan lah sebuah hal negatif. Karena Jarkasi pun yakin kalau hal yang dilakukannya adalah hal yang baik. Mengembangkan budaya dan mengembangkan kemampuan serta bakat yang ada pada diri manusia. Karena hal tersebut merupakan tindakan mensyukuri segala pemberian Tuhan, berikut kutipannya;

Jarkasi sendiri sampai saat ini, selain mengurus lima buah rumah petak yang dikontrakkan, juga tak pernah absen mengurus kelompok gambang kromong meskipun nyaris tak ada lagi orang 
yang menganggap kesenian tradisional itu (Kumala, 2009:45).

Jarkasi bergabung dengan kelompok gambang kromong ketika ia berusia 15 tahun. Waktu itu, setelah melihat upacara dan mendengarkan Bung Karno pidato, ia dan kakaknya mengayuh sepeda hingga Lapangan banteng dan menonton sekelompok musik tanjidor ngamen di sana (hlm 46).

Banyak kebudayaan yang mempunyai satu unsur kebudayaan atau beberapa pranata tertentu yang merupakan unsur pokok dalam kebudayaan mereka, sehingga unsur itu disukai oleh sebagian warga dari masyarakatnya, dan dengan demikian, mendominasi banyak kegiatan atau pranata lain dalam kehidupan masyarakat mereka. Suatu kompleks unsur kebudayaan yang tampak sangat digemari oleh warga dari suatu masyarakat, sehingga seakan-akan mendominasi seluruh kehidupan masyarakat tersebut, oleh ahli antropologi dari Amerika, R. Liston, disebut Culture Interest, atau Social Interest. (Soelaeman, 2006:38).

Jarkasi adalah salah satu contoh seseorang yang bersedia mengembangkan dan melestarikan kebudayaan merupakan wujud nyata dari masyarakat Betawi. Hal itu dilakukannya dan tetap mempertahankan keinginannya untuk selalu meyakini bahwa kebudayaan merupakan hal penting yang menjadi ciri khas dari sebuah dasar hidup keutuhan bermasyarakat, berbangsa dan bernegara. Walaupun pada kenyataannya terdapat banyak halangan yang harus dihadapi guna pemertahanan dan pelestarian kebudayaan tersebut. Sebuah kebudayaan yang dimiliki oleh suatu masyarakat yang merupakan wujud nyata dari ciri khas suatu daerah, yakni Betawi.

\section{PENUTUP}

Terbitnya novel Kronik Betawi cukup menarik perhatian bagi pembaca dan peneliti. Hal tersebut dikarenakan novel mengisahkan beragam cerita menarik yang merupakan potret kehidupan masyarakat Betawi. Dalam novel telah disebutkan bahwa ideologi hampir sama dengan keyakinan agama. Bedanya hanya pada kenyataan bahwa ideologi mampu dipindahkan, ditransmit melalui pendidikan, ajaran dan latihan tanpa melibatkan unsur rohani di dalamnya. Maka kekuatan ideologi merupakan suatu sistem kepercayaan umum yang secara langsung memotivasi dan membenarkan segala hal yang diyakininya, karena ideologi sangat erat kaitannya dengan agama. Ideologi masyarakat Betawi yang mampu menunjukkan kekuatannya untuk menjadikan dirinya dan orang di sekitarnya untuk menemukan hidup kearah lebih baik tercermin dalam tokoh Juned yang telah mempertahankan dirinya, yang bermula hidup seorang diri tanpa sanak saudara hingga mempu menemukan kehidupannya yang lebih baik dengan memiliki keluarga. Dalam tokoh Jarkasi, merupakan seseorang yang bersedia mengembangkan dan melestarikan kebudayaan merupakan wujud nyata dari masyarakat Betawi.

Hal tersebut dilakukannya dan tetap mempertahankan keinginannya untuk selalu meyakini bahwa kebudayaan merupakan hal penting yang menjadi ciri khas dari sebuah dasar hidup keutuhan bermasyarakat, berbangsa dan bernegara. Dalam tokoh Haji Jaelani, yang tak ingin anaknya dikawini oleh lelaki sembarangan. Haji Jaelani ingin anaknya memiliki suami yang benar-benar beragama baik. Maka tidak salah jika Haji Jaelani benar-benar ingin menguji siapa pun yang mendekati atau pun yang ada di dekat Enoh dalam hubungan spesial/pacar. Dalam tokoh Jiung, yang tidak berhenti begitu saja dalam hal sembahyangnya dalam pencak silat. Ilmu yang dimilikinya diturunkan kepada 
Juned dan orang-orang yang pernah merampok Juned. Orang-orang yang dipercaya oleh Juned dan telah dianggap sebagai keluarga. Agar kelak ada yang menuruni segala sesuatu yang mungkin kelak dapat diperlukan oleh masyarakat yang membutuhkan bantuan. Jiung hanya berharap agar pencak silat yang diturunkannya bukan untuk berkelai atau mencari musuh. Tapi untuk membela diri dan menyelematkan orang-orang yang membutuhkan pertolongan, tidak untuk semacam perlindungan fisik, tetapi juga tidak untuk keindahan atau untuk menaikkan gengsi semata.

\section{DAFTAR PUSTAKA}

Alfia, Nazwa. 2008. Klasifikasi Masyarakat Betawi. http://www.wordpress.com, diakses pada 19 Mei 2010.

Damono, Sapardi Djoko. 1979. Sosiologi Sastra Sebuah Pengantar Ringkas. Jakarta: Pusat Pembinaan dan Pengembangan Bahasa.

Faruk. 2005. Pengantar Sosiologi Sastra. Yogyakarta: Pustaka Pelajar.

Fathoni, Abdurrahmat. 2006. Antropologi Sosial Budaya. Jakarta: Rineka Cipta.

Kumala, Ratih. 2009. Kronik Betawi. Jakarta: Gramedia Pustaka Utama.

Ricoeur, Paul. 2012. Hermeneutika Ilmu Sosial. Terjemahan Muhammad Syukri. Yogyakarta: Kreasi Wacana.

Setiawan, Budi. 2009. Kekuatan Suatu Ideologi. http://www.google.co.id, diakses pada 19 Mei 2015.

Soelaeman, M. Munandar. 1987. Ilmu Sosial Dasar Teori dan Konsep Ilmu Sosial. Bandung: Refika Aditama.

Tubbs, Stewart dan Sylvia Moss. 2005. Human Kommunication Konteks-konteks Komunikasi. Bandung: Remaja Rosdakarya. 